\title{
住民に定額家賃で継続居住を保障する民営化による住宅団地の再生手法
} 一郊外型の住宅団地をモデルとした事業化可能性一

\section{THE METHOD OF RENOVATION OF HOUSING ESTATES BY COMMERCIAL FUNDS THAT ENABLES DWELLERS TO STAY AS LONG AS THEIR LIVES IMPOSING STABLE RENT}

- The feasibility study of the method of renovation based on the simulation of housing estates in suburbs-

小山雄二**, 瀬口哲夫**

Yuji KOYAMA and Tetsuo SEGUCHI

The purpose of this paper is to suggest a new method for reconstruction of old public housing. It emphasizes the use of private funds by special purpose companies and leads to reconstruction of housing following the demands of residents, such as guarantee of houses for elderly people, keeping of the quality of environment, and establishment of intergenerational communities. This is different from the rebuilding with public budget, because it reuses the houses that exist now and meets the various demands of residents.

\section{Keywords : Public housing, Reconstruction, Housing estates, Residency of elderly people, Privatization} 公共住宅 再建 住宅団地 高路者居住 民営化

1. はじめに

\section{1 研究の背景}

国及び地方公共団体が財政危機に直面し、今後も公共事業に対す る予算の縮小が避けられない。このような社会全体の流れのなかで 特に古い住宅団地に住む世帯の高齢化が進んでいるため、社会的な ケアを含めた総合的な住宅政策が求められている。具体的には、高 度経済成長の後期に大量に供給された公的な賃貸住宅団地における 全面建替え方式による再生手法の見直しが急務である1)。

戦後に建設された公共住宅の建替えが本格化したのは 1970 年代 である2)。その当時から最近までに発表された既往の研究や調査報 告書をみると、建替えによる再生事業の問題点が様々な視点から繰 り返し指摘されてきている。しかし、指摘されてきた問題の解決が 図られたとはいえず、また、積極的にその問題の解決に向けた具体 的な再生手法を提案した研究はほとんどみられない。

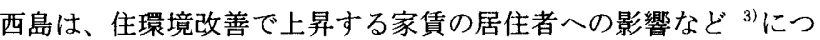

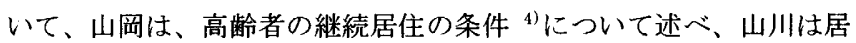
住水準より家貨水淮を優先すること ${ }^{5)} に$ 疑問を呈している。先行す るこの時期の研究では、建替えによる居住水淮の改善メリットを肯 定しながらも、家賃上昇には問題があることを指摘している。

瀬戸口は、住民の意向の多様性 ${ }^{6)}$ について、竹原は、建替え後の

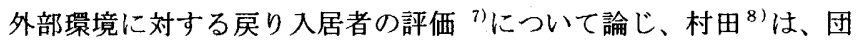
地計画づくりに扔ける住民参加の重要性から、兽 ${ }^{9}$ は、サスティナ ブル・コミュニティの解明から、居住者の意向を更新計画に取り入 れるべきだと主張した。最近の研究では、劉、新井、増永らが、高

* 名古屋市立大学大学院芸術工学研究科 博士後期課程

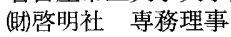

** 名古屋市立大学大学院芸術工学研究科 教授 - 工博
齢化した住宅団地の調査により住宅に対する居住者の具体的な評価 を明らかにした ${ }^{10)}$ が、それらの研究成果は 1993 年に瀬戸口が指摘 した問題点がいまだ解決されていないことを明らかにしたといえよ う。

\section{2 研究の目的}

本稿の目的は、公的な賃貸住宅を対象に、これらの問題点を解消 できる新たな再生手法を提案し、その手法に則った具体的な事業モ デルを検証することである。筆者は、瀬戸口が前揭の論文で明確に 指摘したように、これまで住宅団地の更新計画が当事者である居住 者の意向をほとんど反映できないまま実行されてきたこと阽が、団 地再生の問題の背景にあったと認識している。

筆者は、これまでの研究で指摘されてきた団地再生の問題点は、 「家賃の上昇」「既存環境の破壊」「コミュニティの喪失」の三つに 大きく集約できると考えている。家賃の問題は、建替えや改修など 更新事業を契機にした家賃の值上りによって、低所得、特に高齢者 世帯が本人の意志に反する転退居を迫られるなど、生活不安に直結 することである。環境の問題は、管理者が、住宅更新時に土地を有 効活用する名目で、住戸数や駐車場を增やす建替えや、事業費の回 収を図るために余剩地を売却するなど、成熟した生態系や見慣れた 景観の破壊が避けられないことである。事業効率を優先する全面建 替え方式によって、住民たちの生活で培われたコミュニティを瞬時 に解体する ${ }^{12)}$ 、といったことが住民の批判の対象となっている。

そのことを踏まえて、筆者は、新たな団地再生手法の前提として、 （1）高齢者の継続居住を保障する（2）良質な住環境を保全する Doctor Course, Graduate School of Design and Architecture, Nagoya City University 
（3）地域コミュニティを継承する、という三つの計画条件を設定し た。これらの条件に従って、更新時期を迎えた住宅団地の再生の事 業が成立するか、その事業化可能性を検証するのが本稿の研究の目 的である。その条件を言い換えれば、住民の居住ニーズにあわせた 改修を行うがその費用は家賃に転嫁しない、設備の老朽化と機能の 陳腐化がすすむ住宅を改修し住宅ストックとして活用する、環境を 毀損ぜずに再生に必要な資金を調達し自立した運営を行う、という ことに他ならない。その結果として、従前居住者の継続居住が可能 になり、再生のプロセスで古い住宅を徹底して活かすことでコミュ ニティや環境が毁損されることはなくなると筆者は考えている ${ }^{13)}$ 。

次章では、従来の再生手法と筆者が提案する再生手法の違いにつ いて述べ、従前居住者に定額家賃で継続居住を保障するための計画 与件を明らかにする。第 3 章以降で、郊外型の貸貸住宅団地をモデ ルに、持続可能な再生事業と団地運営の可能性について検証する。

\section{2 研究の方法}

本研究は、更新時期を迎えた公的な賃貸住宅団地 ${ }^{14)}$ について、従 来の全面建替えに代わる再生手法の有意性を示すことである。今回 は、大阪府と兵庫県の複数の住宅団地からえられたデータを参照し ながら、一般的な再生事業モデルに対して検証を行うものである。

\section{1 従来の再生手法と提案する再生手法の違い}

まず、スクラップアンドビルドを繰り返す従来の再生手法と、本 稿で筆者が提案する持続可能な再生手法の違いを指摘しておきたい。 前者の手法は、法定の更新時期が超えれば住宅の媔用年数に関倸 なく全面的に建替えることが基本 ${ }^{15)}$ である。一時期に財政負担が集 中するため、財源不足を補う目的で住棟の集約化・高層化で余剩地 を捻出する場合が多い。また公有財産の処分や住戸数の維持、予算 の消化期限など法的な制約によって、住民の意向と関係なく短期間 で事業を完了させなければならない事情もあり、既存住民の他、近 隣住民からも批判を受けることが多い。

一方、後者の再生手法は、再生事業の民営化を前提に民間資金を 導入し、公的予算の制限を外すことで可能になる、改修による住宅 ストックの活用、定額の低家賃の継続居住保障、土地区画の払下げ、 福祉サービスの提供など、住民本位の事業手法である。住民の世代 交代と世帯構造の変化に合わせて長期的かつ段階的に住戸の改善を 続けるには、安定資金の供給の確保が不可欠である。

\section{2 新たな再生手法の前提条件と具体的な課題}

これまでの団地再生手法に対する批判は、住民の意向と、一定期 間で機械的に建替える硬直的な行政の考え方が対立する点に集中し ていることは 1.2 研究の目的の項で述べた。筆者が提案する事業手 法では、計画の初期段階で住民と事業者がそれらの対立点を解消す る条件設定を認識していることが前提である。その条件を改めて計 画条件として整理する。条件は次の三点に集約される。

（1）従前居住者に従前の家賃水準で継続居住を保障する。

（2）緑豊かな良質な住環境亡都市景観を保全する。

（3）高齢者の暮らしを支える地域コミュニティを継承育成する。 具体的な事業のプログラムでは、まず住民が団地再生に対する住 民の意向を居住者の権利として確定する手続きがある。そのうえで 事業者はそれらを具体的に再生計画に反映しなければならない。
「居住者の権利を統率する住民の自治組織」と、「住民の意向に沿 って住宅団地を運営できる事業体制」の存在が鍵をにぎるが、本章 以下で、この住民参加と事業体制について論証を進める。

\section{3 住民による管理組織と事業組織}

これまでも、再生計画づくりの段階で実際に住民を参加させてい るケースが各地でみられる。当初は行政手続きの一部で、形式的な ものと見られたが最近は一定の成果を上げるケースも増えているよ うだ。しかし、住民参加はあくまで事業者の容認できる範囲の意見 表明のレベルに止まり、再生事業の内容を左右するような主体的な 役割を担うケースはほとんどみられない16)

団地運営で実効性のある住民参加を実現するには、住民が主体的 な立場と責任を明確に表明して、住民の総意を代表する何らかの法 人格をもつ組織が不可久である。住民が自らの要求を集団の権利と して確立したうえで住宅管理者と協議し、その結果について対外的

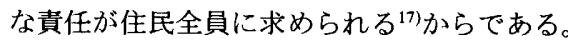

一方、公共団体等から住宅団地の誶渡を受けて再生事業を担うこ とのできる事業主体は、その事業範囲を特定の住宅団地の再生事業 と管理運営に限られる。筆者は、その非営利組織を特定目的会社 （S P C）と考えている ${ }^{18)}$ 。公営住宅法では、いわゆる組合住宅と よばれる形19)で住民の団体が直接払下げを受けることも法的に可能 である。S P C は、住民と合意された再生事業計画があれば必要な 資金を金融市場から調達できるが、住民団体が、民間金融機関から 直接調達するのは難しいだろう。住民が、S P C と協力しながら住 宅団地の管理運営において主導的な役割を果たすことが、そのコミ ュニティとしての役割だと筆者は認識している。

\section{4 団地再生のプログラムの基本構造}

住民組織と事業組織の役割と責任について、住民団体と S P Cの 関係を中心に整理する。下記の図 1 は、両者の関係を事業全体の構 造のなかに位置付けて説明する資料である。

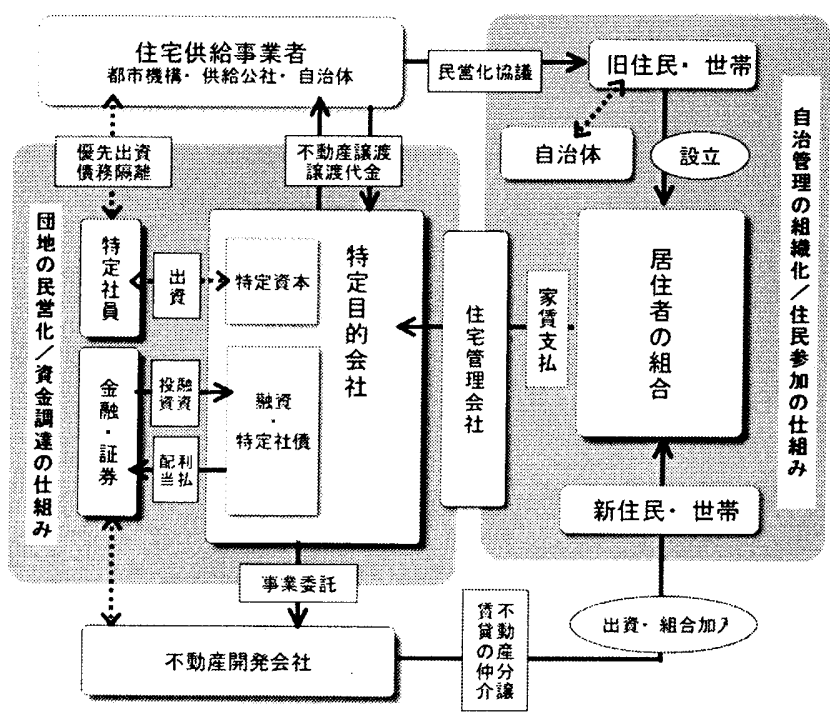

図 1 住宅団地再生事業の構成

再生事業に必要な様々な組織や団体の性格及び各々の役割と責任 は、次章で述べる具体的な再生事業モデルのなかで改めて説明する 
が、次の 10 項目は、事業構造のプログラムの組成に必要な基本方 針を定めたものである。

（1）土地建物の所有権と居住権は完全に分離する。

（2）住民としての諸権利は住宅居住者の組合が統率する20)。

（3）S P C は資産流動化法に基づいて運営を拘束される。

（4）組合は従前居住者一の公的な生活支援継続に責任を負 ${ }^{21)}$ 。

（5）従前の高齢者世帯の終身居住権は譲渡又は相続できない22)。

（6）居住者が退去した住戸は再生計画に従って活用する。

（7）S P C は、街の景観と良好な自然環境を保全する責任を負う。

（8）S P Cは、住宅団地内に福祉施設を整備または誘致できる。

（9）住宅団地の維持管理に必要な資金はS P Cが調達する23)。

（10）組合はＳＰＣが調達した資金に対して債務保証をしない。

\section{5 住宅団地再生の計画プログラム}

\subsection{1 対象となる団地の選定}

本稿で提案する団地再生のプログラムは、以下のような具体的な 対策が急がれる公的な賃貸住宅団地を対象としたものである。

（1）開設後、法的な耐用年数 70 年の半期を経過し更新時期を迎 えた団地。

（2）壁式構造のため耐震強度に問題が少ないとされる中高層住棟 で構成される団地 ${ }^{24)}$

（3）標淮世帯の最低居住水準に満たない約 $32 \mathrm{~m}^{2}$ から $50 \mathrm{~m}^{2}$ 位まで の比較的狭い住宅が残っている団地。

（4）階段室アプローチ型の住棟が多く、昇降機の設置費用の負担 が割高となる団地。

（5）継続居住を望むが家賃上昇に対する負担力がない低所得の高 齢者世帯の割合が高い団地。

ただし、すでに補助金によって改修又は一部が建替えられた団地、 もしくはすでに団地の一部の敷地が民間企業に譲渡された団地は、 本提案の対象ではない。

\subsection{2 計画の指標となる世帯数の变化予測}

筆者が本稿で提案する具体的な事業プログラムで基本的な指標と したのは、再生事業に着手した時の年代別世帯の構成率と同世帯数 の将来推計值である。一般的に、世帯数の変化は、単身世帯主の死 亡・結婚・出産・離婚 - 子供の独立 - 別居等の自然的要因による他、 一定の地域内の変化をみる場合は世帯の転出入という社会的な要因 が影響する ${ }^{25)}$ 。ここで世帯数と人口の変化を比較して、その影響の 範囲をみてみる。

表 1、表 2 は、国立社会保障・人口問題研究所の人口と世帯数の 将来推計 ${ }^{26)}$ を使って、全国の 10 歳階級世代別の世帯数と人口の将 来の変化を推計した結果である。2000 年から 10 年ごとに各世代の 世帯数と人口がどのように変化するかを予測している。その結果を みると、2000 年時点で 25 歳以上の世帯主の世帯約 4399 万世帯が、 20 年後には 3747 万世帯と $17.1 \%$ 減少するが、65 歳以上の世帯は同 期間で $77.7 \%$ 減少している。年代別に世帯主が 25 歳から 34 歳の世 代は 20 年加齢まで世帯数の増減比率が人口の比率を上回っている が、その後は世帯数と人口の比率と同じように減少し、75 歳を超え たあたりで世帯数の減少が加速するのがわかる。加齢による親子同 居も含め、その期間を中心にいわゆる「家督相続」的な世代交代が 行われるものと考えていいだろう。なお本稿では、世代別世帯を区
分する 10 歳階級の表記を、初年度の世帯主年齢ごとにA（15 歳一 24 歳) B (25 歳一34 歳)、以下 I (95 歳一) とした。

表 1 全国の10歳階級別世帯主の世帯数推移（単位: 千世常)

\begin{tabular}{|c|c|c|c|c|c|}
\hline 䄸級（初年度年艊) & 2000年 & 增娍率* & 2010年 & 增堿事* & 2020年 \\
\hline A (15 24藏) & 2.798 & $207.5 \%$ & 5,807 & $265.8 \%$ & 7,437 \\
\hline B (25 34歲) & 6,711 & $128.6 \%$ & 8,628 & $144.4 \%$ & 9,693 \\
\hline C (35 44歳) & 7,081 & $114.7 \%$ & 8,122 & $117.3 \%$ & 8,306 \\
\hline D (45 54藏) & 9,929 & $101.4 \%$ & 10.069 & $94.5 \%$ & 9.387 \\
\hline$E$ (55 64尉) & 9.127 & 92. 9\% & 8,483 & $72.3 \%$ & 6,600 \\
\hline$F(65 \sim 74$ 留) & 7,193 & $76.6 \%$ & 5,512 & $32.8 \%$ & 2,359 \\
\hline G (75 84缄) & 3,257 & $41.2 \%$ & 1,341 & 3. $8 \%$ & 124 \\
\hline H (85 94䆣) & 653 & $10.7 \%$ & 70 & $0.0 \%$ & \\
\hline I (95葴一) & 34 & $0.0 \%$ & & & \\
\hline A〜I世代世蒂数 & 46,783 & $102.7 \%$ & 48,032 & $93.9 \%$ & 43,906 \\
\hline 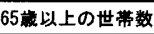 & 11,137 & $138.3 \%$ & 15,406 & $165.8 \%$ & 18,470 \\
\hline
\end{tabular}

表 2 全国の10年階級別の人口推移 (策位: 千人)

\begin{tabular}{|c|c|c|c|c|c|}
\hline 陵級 (初年度年龄) & 2000年 & 增減事* & 2010年 & 増減率* & 2020年 \\
\hline A $(15 \sim 24$ 歲) & 15,940 & $79.7 \%$ & 12,700 & $74.2 \%$ & 11,824 \\
\hline B (25 34嵅) & 18,603 & $99.8 \%$ & 18,565 & $98.2 \%$ & 18,259 \\
\hline C $\quad(35 \sim 44$ 盛) & 15,944 & $98.2 \%$ & 15,651 & 94. $1 \%$ & 15,001 \\
\hline D $(45 \sim 54$ 咸 $)$ & 19,392 & $95.5 \%$ & 18,518 & $87.1 \%$ & 16,893 \\
\hline E $(55 \sim 64$ 咸 $)$ & 16.499 & $90.6 \%$ & 14,941 & $71.8 \%$ & 11.850 \\
\hline$F(65 \sim 74$ 嵅) & 13,028 & $77.5 \%$ & 10,091 & $42.4 \%$ & 5.526 \\
\hline G (75 84藏) & 6,775 & $51.9 \%$ & 3,516 & 4. $3 \%$ & 291 \\
\hline H (85 944嵅) & 2,125 & $8.7 \%$ & 185 & $0.0 \%$ & 1 \\
\hline 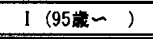 & 112 & $0.9 \%$ & 1 & & \\
\hline AーI世代の人口 & 108,418 & $86.9 \%$ & 94,168 & $73.5 \%$ & 79.645 \\
\hline 65藏以上の人口 & 21,928 & $131.0 \%$ & 28,734 & $157.6 \%$ & 34,561 \\
\hline
\end{tabular}

\subsection{3 社会的要因を加味した世帯数の変化予測}

表 3 は、神戸市の公営住宅入退居数から、実在する神戸市のS 団 地の過去 10 年間の 10 歳階級別に世帯数の増隇を表したものである。 前揭の全国の 10 年間の増減率と比べると 45 歳から 75 歳までの世 帯数の増減率がほぼ同じ傾向を示している ${ }^{27)}$ 。75 歳以上の高龄世帯 と 45 歳未満の若年世代の増減率が、全国の予測数值と大きく異な っており、これらの両極の世代の入退居は社会的な要因によること が判る。S団地の 10 年間の退居世帯数は 1216 世帯であり、全世帯 数に対して $55.1 \%$ （年率換算 7.7\%）であるが、徐々に低下寸る傾 向が見られ、直近の 2005 年度の年間退居率は $4.5 \%$ となっている。

\section{表 3 神戸市S 団地の世帯数の増減率／実績値 (単位: 世蒂)}

\begin{tabular}{|c|c|c|c|c|c|}
\hline 階級（初年度年数） & 1996年 & 增減㪄* & 2001年 & 堙娍率* & 2006年 \\
\hline$A \quad(15 \sim 24$ 瓷 & 37 & $267.6 \%$ & 99 & $308.1 \%$ & 114 \\
\hline B $(25 \sim 34$ 㓊) & 275 & $70.5 \%$ & 194 & $61.1 \%$ & 168 \\
\hline C $(35 \sim 44$ 瓷 $)$ & 297 & $76.4 \%$ & 227 & $69.4 \%$ & 206 \\
\hline D $(45 \sim 54$ 瓷) & 549 & $93.8 \%$ & 515 & $94.7 \%$ & 520 \\
\hline$E \quad(55 \sim 64$ 紫) & 532 & $104.9 \%$ & 558 & $106.6 \%$ & 567 \\
\hline F $(65 \sim 74$ 藏 $)$ & 345 & $96.2 \%$ & 332 & $79.4 \%$ & 274 \\
\hline G $(75 \sim 84$ 䨋) & 155 & $74.8 \%$ & 116 & $44.5 \%$ & 69 \\
\hline H (85 94嵅) & 17 & $58.8 \%$ & 10 & $17.6 \%$ & 3 \\
\hline $1(95$ 蹢 & 1 & $100.0 \%$ & 1 & $0.0 \%$ & 0 \\
\hline AーI世代世帝数 & 2,208 & $92.9 \%$ & 2,052 & $87.0 \%$ & 1,921 \\
\hline 65諴以上の世需数 & 518 & $138.4 \%$ & 717 & $176.3 \%$ & 913 \\
\hline
\end{tabular}

一定の地域や個々の住宅団地では、転出入という社会的増减と世 帯分離による世帯数の変化が発生するが、社会的要因による入退居 率は、団地の立地環境・開発時期だけではなく社会や経済環境の影 
響を受け、個々の団地や時代によって異なってくる ${ }^{28)}$ 。次章以降で、 既存住戸に従前居住者の継続居住を保障する一方、事業着手後、外 部から老朽化した既存住棟への入居を停止する条件で事業モデルを 設定し、検証をすすめる。

\section{3. 段階型な団地再生を実現する事業モデル}

本研究で提案する民間資金を活用する団地再生手法は、国際的な 金融市場と連動したボーダーレスな資金の導入を念頭においている。 事業資金の調達手段は極めて多様化しており、事業性の可否の判定 を客観的かつ迅速に行うには、再生事業の事業化可能性の判定に必 要な計画与件はできるだけ単純化しておく必要がある。

本章では、大阪府下の住宅団地をモデルに、再生事業の判定に必 要な計画与件を事業規模・期間に関する項目と事業収支に倸わる項 目に整理して条件を仮定して事業プログラムの検証を行う。

\section{1 公的な貨貸住宅団地の民営化に必要な計画与件}

住民に対する継続居住保障は、高齢者にとって実質的に終身居住 保障であり、筆者が計画の前提とする次の条件は、居住者と原管理 者の間の約束事として、S P Cの事業運営を完全に拘束するもので あると考えている。以下に計画与件を改めて整理しておく。

（1）65 歳を超える世帯主及び配偶者には、同一条件で終身居住権 を認める（配偶者以外の同,居親族は同一条件を適用しない）

（2）65 歳以下の世帯については、住棟の耐用年数を目処に定期借 家契約に基づく継続居住権を認める（同前項の但し書）

（3）高齢者世帯には、昇降機及びスロープを設置した住戸住棟に 優先的に居住する権利を認める。

（4） S P Cは、高齢者の終身居住の保障を担保するため 24 時間 介護サービスを供給する福祉ケア施設を団地内に整備し維持 する責任がある。

（5）S P C は、改修・修繥・補修など住宅ストック活用に必要な 費用を負担し、その費用を家賃に転嫁してはならない。

（6）居住者が、当初の取り決めに従って団地内で転居する場合は、 転居費と転居先の住戸修縓費については管理者が負担する。

（7）従前居住者柱前家賃を維持されるが、単位面積の単価で家 賃に上乗せすることで自らの希望及び判断の元で住戸面積を 增やす改修もしくは広い住戸に転居することができる。

（8）建物の管理者責任の範囲を超える住戸内の改修に関する費用

は、居住者の負担とし家賃に上乗せして支払うことができる。

\section{2 住宅団地再生の事業性の検証に必要な計画与吽}

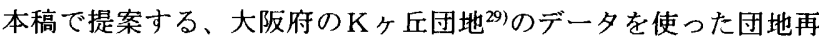
生の事業モデルは、事業プログラムを検証するためのものである。 筆者はこの作業自体を、詳細な事業化可能性調査 ${ }^{30)}$ の前段階の検討 作業と位置付けている。このような検証の目的は、住宅団地の現管 理者が、金融証券市場を背景にした住宅団地の資産評価を把握する ことと、資金提供側の民間金融機関等が再生事業の資金需要を量る と同時に事業リスクを判断しお互いに具体的な検討作業に進むか否 かを検討すること、の二点である。

\section{3 世帯数の推移予測の前提条件}

本章で検証する事業モデルは、大阪府下枚方市の $\mathrm{K}$ r丘公団住宅 団地である。本章の冒頭で示した公的な賃貸住宅団地の再生事業プ
ログラムの検討に必要な与件は、次の通りである。各項目に対応し たKヶ丘団地の実際のデータを与件として設定している。

表4 事業モデルとした住宅団地の条件

\begin{tabular}{|c|c|}
\hline \multicolumn{2}{|l|}{ A；事業期間の検討項目 } \\
\hline (1) 建設年月（耐用年数予測） & 1958年 \\
\hline (2) 総住戸数（入居世帯数） & $1024 \overline{(819 \bar{戸})}$ \\
\hline （3）年齢別世带構成率 & 表 5参照 \\
\hline (4) 平均退居率 & $4.0 \% /$ 年 \\
\hline \multicolumn{2}{|l|}{ B：事業収支の検討項目 } \\
\hline （5）住棟数（住棟タイプ、階数） & 34 棟 (4〜13階) \\
\hline （6）平均住戸専有面積 & 平均 $40 \mathrm{~m}^{2} / \bar{戸}$ \\
\hline (7) 平均月額家貨 - 共益費等負担額 & $42,000 \mathrm{M} /$ 月 \\
\hline (8) 団地周辺宅地の平均路線価 & $120,000 \mathrm{~m} / \mathrm{m}^{2}$ \\
\hline $\begin{array}{l}\text { (9) 団地敷地有効面積 } \\
\text { (公道、公園等を地面積) }\end{array}$ & $51,000 \mathrm{~m}^{2}(*)$ \\
\hline
\end{tabular}

事業モデルでは、再生事業の着手時で入居募集を停止することを 前提にするが、図 2 のグラフは、全面的な建替えのため実際に 2000 年から募集を停止している神戸市の T団地の 10 歳階級別の世帯数 の変化 ${ }^{31)}$ 表したものである。2001 年以降は新規入居がなく、社会 的要因による退居率を想定する参考データとすることができる。

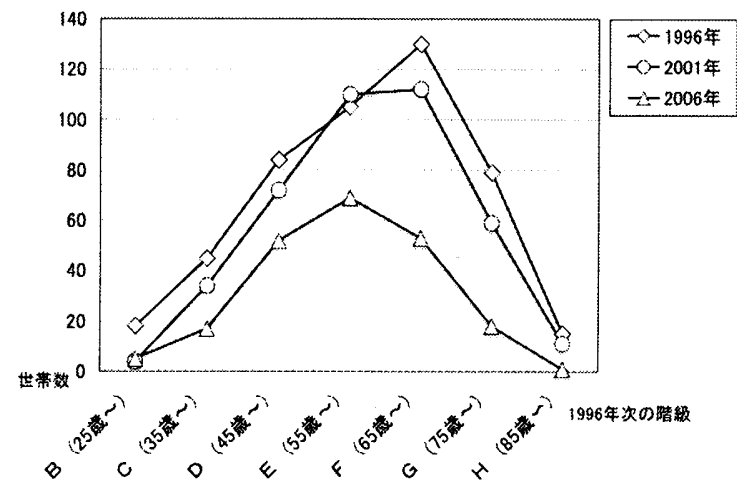

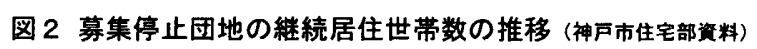

このグラフをみると、2001 年以降の退居率が大きくなっているが、 これは神戸市が高齢者世帯の引越先を積極的に斡旋しているためで ある。しかし、高齢者の継続居住を保障した場合、2.5.3 で示した ように平均的な世帯减少率を下回ることは考えられず、事業モデル の退居率の想定においては、65 歳を超えた高齢者世帯の堿少率 $4.0 \%$ 年を採用する。 T 団地の 55 歳未満である B、C、D階級世 帯の 10 年間の退居率は $33.1 \%$ (年率換算で $6.6 \%$ ) である。E階 級はこれまでの資料の検証から増减なしとみなしている。

本項で提案する事業モデルの事業期間は最低 20 年を目標として いる。新規入居の停止を前提にした事業モデルで将来世帯数を推計 するにあたって、事業着手時に 55 歳未満の世代の減少率は、これ まで検証した過去の実績データを参照して社会的な要因による退居 率を採用、65 歳以上の世帯主世帯数の推移は、社会的な転出入がな いものとして算出する。このような前提条件で、事業モデルとした 大阪府の Kr 丘団地の世帯構成に增減率をあてはめて、世帯数の将 来推計を求め、次項以下で事業モデルの検証を試みる。 


\section{4 事業モデル団地の将来世帯数の算出}

表 5 は、筆者が再生事業モデルとしたKヶ 丘団地の 20 年後の将 来世帯数を推計したものである。現在、住戸数は 1024 戸であるが、 2004 年の調查時では入居世帯は 819 戸である。前項までの考察から、 新規入居募集を停止した団地における減少（退居）率は、事業着手 時に世帯主が 55 歳未満の世帯数については、社会的な要因による 退居率を、65 歳以上の世帯については一般的な高蹫者世帯の減少率 を採用した。団地全体の減少率は、10 年間で $32.7 \%$ (年率換算で $3.9 \%$ )、20 年間で $58.5 \%$ (同 $8.4 \%$ ）となる。

\section{表 5 事業モデル団地の従前居住世帯数の推移 (単位: 世菜)}

\begin{tabular}{|c|c|c|c|c|c|}
\hline 階級 (初年度年龄) & 2000年 & 增減事* & 2010年 & 增減率* & 2006年 \\
\hline A (15 24䟫) & 9 & $100.0 \%$ & 9 & $35.6 \%$ & 3 \\
\hline 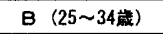 & 58 & $29.4 \%$ & 17 & $11.0 \%$ & 6 \\
\hline C $\quad(35 \sim 44$ 嵅 $)$ & 58 & $37.8 \%$ & 22 & $25.7 \%$ & 15 \\
\hline$D(45 \sim 54$ 䊼 $)$ & 75 & $61.9 \%$ & 46 & $65.3 \%$ & 49 \\
\hline E $(55 \sim 64$ 嵅 $)$ & 215 & $100.0 \%$ & 215 & $81.7 \%$ & 176 \\
\hline$F \quad(65 \sim 74$ 㠔 $)$ & 231 & $76.6 \%$ & 177 & $35.5 \%$ & 82 \\
\hline G (75 84嵅) & 140 & $43.3 \%$ & 61 & $6.1 \%$ & 9 \\
\hline 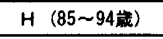 & 31 & $14.0 \%$ & 4 & $0.0 \%$ & 0 \\
\hline $1(95$ 紫 & 2 & $0.0 \%$ & 0 & & \\
\hline Aへ1世代世带数 & 819 & $67.3 \%$ & 551 & $41.5 \%$ & 340 \\
\hline 65蔵以上の世娄数 & 404 & $113.1 \%$ & 457 & $78.0 \%$ & 315 \\
\hline
\end{tabular}

S P C は、事業開始時に、高齢者の継続居住に支障がある住棟や 住戸を集中的にバリアフリー化する改善工事を実施する。エレベー タやスロープを必要とする高齢者世帯に転居を促し、団地全体でバ ランスの取れた住棟配置を残すように計画的に改修・補修工事を実 施、空き家となった住棟から順次除却していく。段階的かつ中長期 的に生みだされる土地は、当初の計画に従った事業用地となる。

図 3 は、世帯数の減少で生じた空き家を集約化して事業用地とし、 団地周辺の環境に合わせて戸建て住宅区画とした場合の、団地の全 体戸数の推移を表したものである。20 年経過後の団地内世帯数を定 常化させることが計画の最終的な目標である。

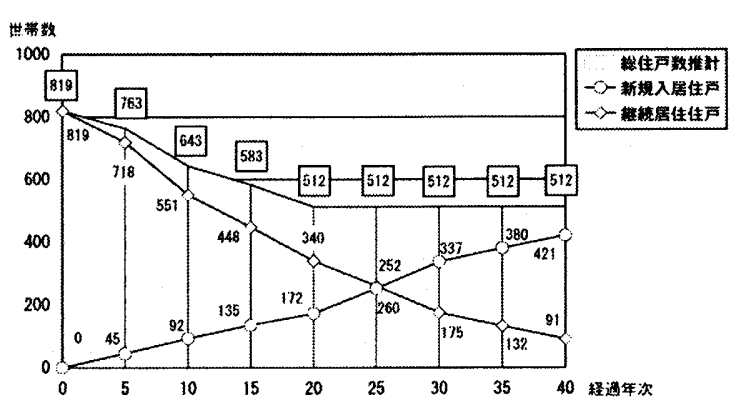

\section{図 $3 \quad K$ 団地の継続居住と新規入居の世帯数推移}

S P C が計画に従ってスムーズに事業を実施するには、団地内の 転居に居住者の協力が不可欠である。これまでは、改修や建替え費 用は必ず居住者に転嫁されたため、住民が転居や転宅を拒否する久 一スが少なくなかった。筆者は、運営を民営化することで、最大の 障害である家賃転嫁を求めない再生が可能になると考えている。住 民に対する継続居住と定額家賃の保障の履行を担保に、継続居住を 希望する全世帯が参加する住民組織と原管理者とのあいだで、団地
内転居に協力する旨を約束した協定（契約）を締結することが事業 の前提条件となり、協定はS P Cが引き継いで施行することになる。

本稿 2.3 と 2.4 で論述した住民の主体的な事業参加は、住民が事 業の運営に一定の責任をもつことであり、S P C は住民の意向を代 理し、事業に必要な資金の調達と専門的な立場で運営を担う。

\section{5 事業予算と事業収支の構造について}

\subsubsection{SPCによる住宅経営の立脚点}

これまでの住宅問題は、国土交通省（旧建設省）がリードするか たちで主に都市と建築系の専門家がその解決策を論じてきた。しか し住宅団地の再生に金融証券市場から資金を導入するには、経済的、 社会的、法律的など、むしろ建筑技術以外に解決す心゙き課題が多い。

筆者は、再生事業の運営主体をS P Cにすることによって公営住 宅をはじめ公的な賃貸住宅事業が担ってきた非営利な側面を継承す ることができると考えている。資本の効率性を優先する企業論理に 従った民間事業と異なり、居住者の経済力に左右されずに住民の意 向を尊重し、地域コミュニティを継承発展させることを事業運営の 目標とすることが、事業の基本にあるからである。

同じようにＳＰＣを事業主体とするＰＦＩ＼cjkstart方式との比較は本稿の 目的ではないが、資金調達と事業費削減が主な目的である我が国の P F I 方式と最も異なる点は、再生事業を担うS P Cの責任と役割 を明確に、従前居住者の住生活支援を優先的な目的とした点にある。

\section{5 .2 住戸改修の考え方と事業支出と収入の算出}

図 4 は、一定の割合で減少する既存住戸と新設住戸の推移である。 事業モデルとしたKケ丘団地の事業プログラムでは、70 年の耐用年 数を超える住棟は、高龄者専用住宅として新たに中高層の貨貸住宅 とし整備する計画とした。住宅ストックを徹底的に活用する方針で、 居住者の生活に支障のないように専用戸内の改善は居住者の健康や 年齢を配慮してS P C 負担で実施、高齢者世帯、障害者世帯から優 先的に改修された住戸に転居することになる。

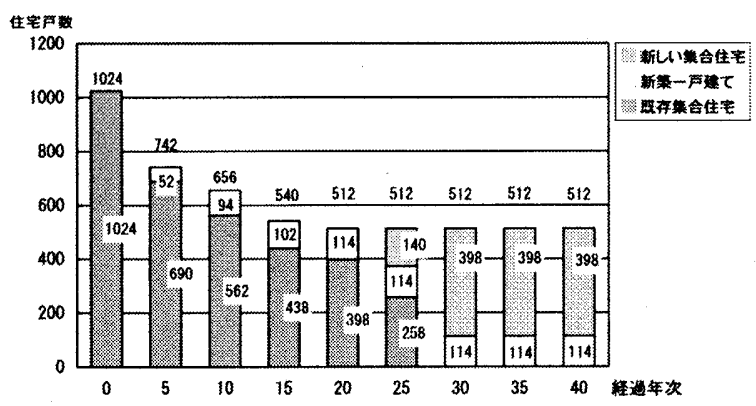

図4K団地の住戸数の推移と将来の総住戸数

S P C が負担する事業費は、老朽化対策、地震対策を含む防災・ 防犯、バリアフリー対策など大規模な修繥や改造工事費用などであ る。修繥・改修の対象は、耐用年数まで長期的に利用することが前 提だが、段階的に空き住棟を除却するため、積算では対象をある程 度限定している。施工は当初 5 年間で、継続的に行う条件下で、昇 降機設置、共有部分の段差解消、構造 (耐震) 補強、防水改修、防 災設備及び基幹設備の更新費用を積算した。

住戸専用部分の改装・改造は居住者の負担となる。ただし、管理 者の要請によって団地内で転居する場合、転居先の専用部分の美 
装・補修費と引越費用はS P Cの負担である。

事業収入は、家賃収入と土地区画の分譲収入の二つである。家賃 はK K 丘団地の平均家賃に、従前居住者世帯数を乗じて算出してい る。集計すると、 5 年目まで 23.2 億円、 6 年から 10 年まで 15.9 億円、11 年目から 20 年目まで 22.1 億円となった。分䛊収入は、生 み出される土地を戸建て区画にした場合の有効専有面積に、2005 年 の路線価を乗じて評価額を算出している。

表6 事業モデルの収支算定指標/Kケ丘団地

\begin{tabular}{|c|c|c|c|c|c|}
\hline \multirow{6}{*}{ 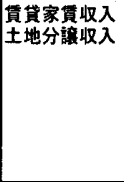 } & 費用の算定期間 & 世需数 & 家䨘収入/千円 & 未利用宅地 & 土地拜洒/千円 \\
\hline & 1年- 5 年 & $718 \overline{\mathcal{F}}$ & $2,320,000$ & $25,245 \mathrm{~m}^{\mathrm{m}}$ & $2,232,000$ \\
\hline & 6 年- 10 年 & $551 \bar{P}$ & $1,590,000$ & $13,778 \mathrm{~m}^{2}$ & $1,444,000$ \\
\hline & 11年- 15 年 & $448 \overline{\bar{P}}$ & $1,243,000$ & $8.498 \mathrm{~m}$ & 441,000 \\
\hline & 16 年- 20 年 & $340 \overline{\bar{F}}$ & 961,000 & $8,910 \mathrm{~m}^{2}$ & 252,000 \\
\hline & \multicolumn{3}{|r|}{ 合部 } & $56,430 \mathrm{~m}$ & $4,369,000$ \\
\hline \multirow{4}{*}{\begin{tabular}{|l} 
住裸解体費 \\
区国造成費
\end{tabular}} & 期閶 & \multicolumn{3}{|c|}{ 摘要 } & 工事贯/千円 \\
\hline & \multirow{3}{*}{\begin{tabular}{r|} 
年- 10 年 \\
11 年- 20 年
\end{tabular}} & \multirow{2}{*}{\multicolumn{3}{|c|}{ 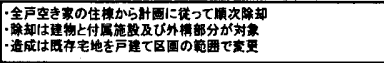 }} & 424,000 \\
\hline & & & & & 692,000 \\
\hline & & & & 含尌 & $1,116,000$ \\
\hline \multirow{6}{*}{ 住居改善费他 } & 期間 & EV設置戸数 & 改喽戸数 & 墒要 & 改愘费/千円 \\
\hline & 1 年- 5 年 & $270 \bar{F}$ & $287 \bar{F}$ & \multirow{4}{*}{ 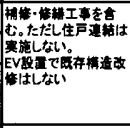 } & $1,781,000$ \\
\hline & 6年- 10 年 & $65 \overline{\boldsymbol{P}}$ & $123 \bar{F}$ & & 510,000 \\
\hline & 11 年- 15 年 & $0 \bar{F}$ & $138 \bar{P}$ & & 339,000 \\
\hline & 16年- 20 年 & $0 \bar{P}$ & $83 \overline{\bar{P}}$ & & 258,000 \\
\hline & 小㗘 & $335 \bar{\nexists}$ & $631 \overline{\bar{I}}$ & 合部 & $2,888,000$ \\
\hline
\end{tabular}

\section{6 事業収支と事業判定}

本研究の目的は、最終的に再生計画で提案した事業が、従前の容 積率以下の住宅面積の開発でも、民間金融機関から資金調達が可能 であることを示唆することである。筆者は、これまでの未利用容積 率を使って確保した新たな床面積を使って事業の採算性を向上させ ようとした再生手法とは異なる事業モデルを提案し、その事業性を 検証することを本稿の目的としている。

図 5 は、Kヶ丘団地で設定した事業モデルにおいて、再生事業の 収支構造と調達資金の性格と金額の上限を判定したものである゙22。
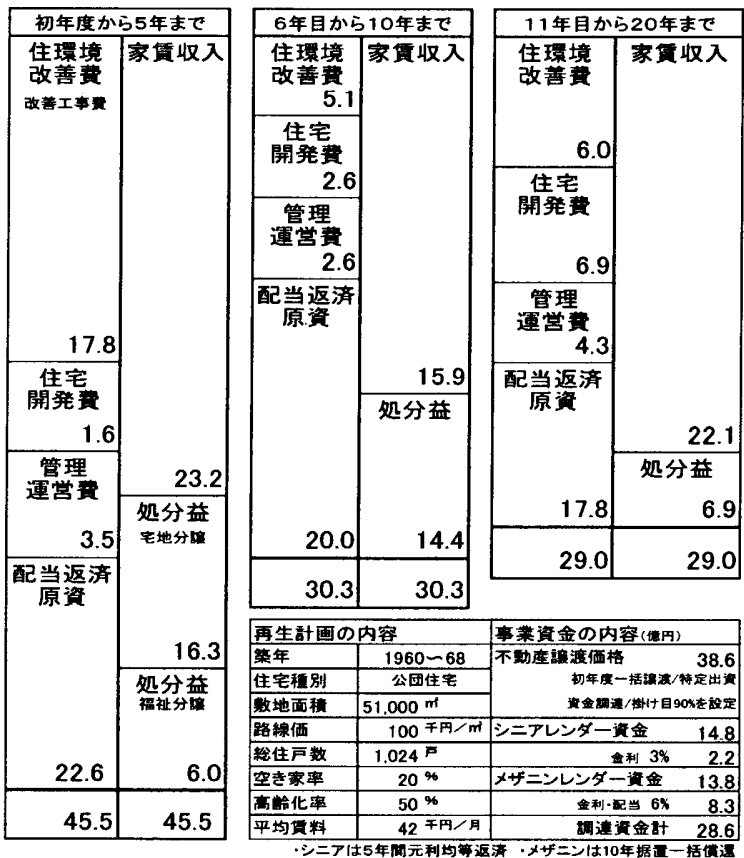

図 5 事業モデルの資金調達可能額と住宅団地の資産価格
事業着手時から最初の 5 年間の総収入 45.5 億円に対し支出は 22.9 億円、差額が調達した資金の配当・利払い・元金返済資金に充 当可能な粗利益である。次の 5 年間では、それが 20.0 億円、10 年 目から 20 年までが 17.8 億円である。S P C が償還請求権を発生さ せずに調達可能な金額から、住宅管理者の譲渡価格を判断できる。

これまで経済的弱者に対する低家賃住宅を運営する公的な貸貸住 宅事業は、民間資本では不動産事業の経済性に合致しない非営利事 業とされ、実際に、地方自治体にとって公的な貨貸住宅事業は赤字 財政政の原因となって久しい。筆者は、低家賃ながら従前居住者の 終身居住権又は定期借家権によって長期的に保証される収入到があ れば、金融市場から安定した低利の長期資金の調達が可能になるこ とを示し、さらに一定の割合で確実に生まれる土地の売却益を前提 で調達できる投資的な資金を組み合わすことによる事業プログラム を構筑した。

図 6 は、K団地の事業モデルの事業収支構造を、賃貸と分蛽益収 入、事業投資的費用と管理費支出、収益の累計額と調達資金と返済 を時系列で比較したものである。K団地の事業モデルでは調達した 資金は 10 年で解消することが判る。

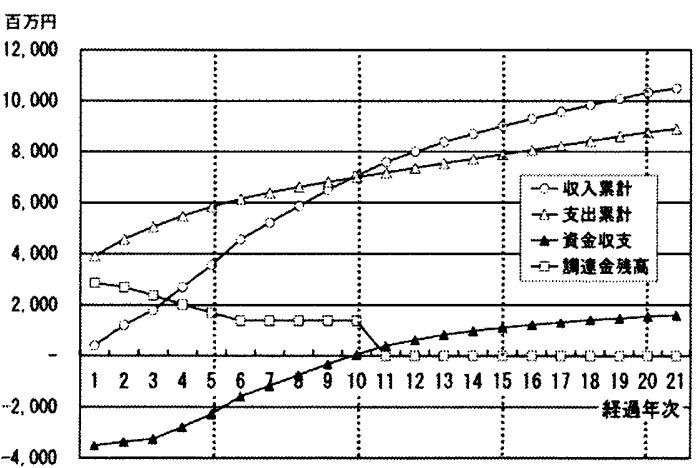

図 6 事業収支と調達資金の返済の流れ

団地という区切られた居住空間で、再生事業着手から 20 年間に わたって新たな入居を制限すれぼ従前の世帯数は大巾に減少するこ とは自明である。事業モデルが示すように、緑豊かな地域の住環境 を守りながら、既存の住棟を可能な限り残しつつ、新たな住戸を建 設して新たな入居者を徐々に増やしていくことによって、持続可能 な多世代が混在して暮らす町に再生できるプログラムは可能である。 未利用容積率を使って短期的に投資回収を要求する再開発型の再 生事業ではなく、長期的な資金と既存のインフラを最大限に利用し、 低容積率と低建蔽率を維持して生まれる新たな住宅用地は、周辺の 良好な戸建て住宅地と一体となってさらに良好な住環境を形成する だろう。巻末の付録 (2)に揭載した事業モデルによる再生計画案に、 除却された住棟の跡地の緑あふれる空間を活かして、周辺の景観に 馿染むように戸建て住宅の宅地を配置していくプロセスと、全体が 良質な住環境として酾成されていく様子がみてとれるだろう。

\section{4. 結語}

筆者が、本研究で目指したのは、公的な賃貸住宅団地の再生手法 についてこれまでの研究で指摘されてきた課題を解決することが可 
能な具体的な再生手法を明らかにすることである。その課題とは、 (1) 従前の居住者の継続居住の保障、（2）緑豊かな成熟した住環境の 保全、(3)濃密な地域コミュニティの継承、の三点である。

住民の主体的な再生事業への参加を前提にしながら、民間資金に よる健全な団地運営の手法を明らかにすることができた。20 年とい う時間をかけて、住宅ストックを最大限に活用することによって、 住民の家貨負担に転嫁することのない住宅団地の再生が実現するこ とを証明できたと考えている。戦後の成長期から建設が続けられて 来た住宅団地は各方面から批判をあびながらも、住宅不足に応えつ つ緑豊かな潤沢な空間を育んできたことは事実である。このような 社会的な価値を、一時の経済的な価値に置き換えることなく保全継 承していくことは、我々世代の義務であると考えている。

\section{5. 今後の課題}

本提案の内容に関連して敢えて問題を提起すれば、公営住宅に対 する需要が増加しているなかで、筆者の提案する再生手法では、今 後新たに住宅団地が形成されない限り確実に公的な貸貸住宅の総戸 数が堿少していくことである。しかし、欧州の例を引くまでもなく 公共が住宅を直接供給する住宅政策の限界は明らかであろう。

筆者は、これまでの住宅問題の研究から、高齡者や生活困笨者、 障害者など、低負担の住宅を必要とする人々に対する具体的な住宅 政策は、個々の生活者に対して住宅手当といった個人給付の形を取 るべきであるという考え方に立脚しつつ今回のプログラムを提案し た、という個人的な背景を附しておきたい。

謝辞 : 本研究では、愛知教育大の小川正光教授、神戸松蕯女学学 院短期大学の増永理彦教授には極めて示唆に富むご指導をいただい た。ここに感謝の意を表したいと思います。

\section{付録（1）用語の定義 :}

本稿で使った用語について主なものについて以下に解説する。

『老朽化』: 国及び地方公共団体は、中高層の耐火建築物に平均的な寿命を設 定しその半分の期間が経過した段階で除却を認め、建替え等を行う更新時期 としている。そのような住宅団地を、一般的に「老朽化した住宅団地」とよ ぶことが多い。しかし、老朽化という語彙には、老朽化=使い物にならない、 「朽ちる」という印象があり、筆者は、筑後 35 年以上経過し建替えなど何ら かの改善が必要となった住宅団地を「老朽化した」と呼ぶことに抵抗がある。 更新時期を迎えた住宅をストックとして活用し、建築物の構造的な寿命を全 うさせることを意図した場合、建築技術的な知識に乏しい住民に不安を与え る恐れがあるからであり、本論文中では老朽化という言葉を避けている。 『更新』: 住宅・住棟の建築物の建替え・改修・增改築・補修・修綁といった 物的な構成要素の範囲で必要とされ改善などの行為と定義している。

『再生』: 単に建築物だけではなく、外部環境の自然や景観の他、地域コミュ ニティや生活支援サービスなど、住民の生活環境を構成する全体を含む対象 を、新たな存在価値を与えるという行為のことをいう。筆者はさらに再生が 目的とする対象には、「人間」「歷史」「文化」を包含するものと考えている。

付録（2）事業モデル計画図（右段上）

本稿の 3 章以下で言及したKヶ団地の事業計画モデルを示す。

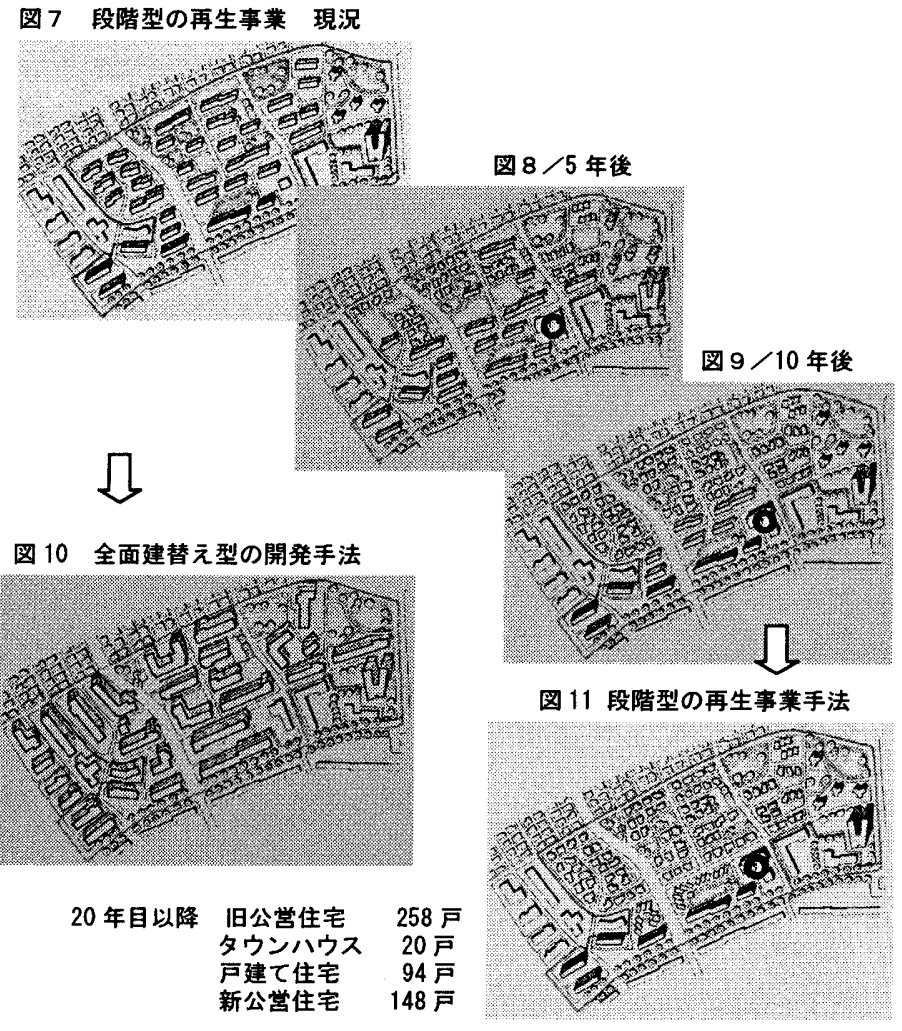

注

注 1) 2000 年 6 月の「住宅宅地審議会」で、我が国の住宅政策は、ストック 重視、市場重視への転換が答申され、2004 年 12 月の社会資本整備審議 会住宅宅地分科会においては、公的儥貸住宅制度の弹力的運用等によっ て公営住宅のストックを活用し、地域のセーフティネットの機能向上の 役割を求めるものとしている。

注 2）耐用年数の二分の一を超えた住宅を建替えることを可能にした 1968 年 の公営住宅法の改正と住宅建設計画法の制定の影響が大きい。

注 3) 西島は、1985 年に行った高知市の公営住宅の調查から、事業効率から 住戸改善より建替えを優先する考え方を批判し、居住性、家賃負担、コ ミュニティの形成など、居住者の立場で世帯特性や収入の差異を考慮し た住宅政策が必要とした。

注 4) 山岡は継続居住の条件を『住宅白書一高齢者と住まいー1998』で明らか にしている。

注 5) 山川は、住宅の建設で家貨水準より社会的ストックとして居住水準を 優先する考え方に疑問を呈している。

注 6) 瀬戸口は、この論文の結論で、管理者である公団主導ですすめられる 団地の更新事業を暗に批判すると同時に、居住世帯の多様な意向を更新 計画に反映させるには、居住世帯による自治管理機能をもつ共同管理組 織が必要だとしている。

注 7) 竹原は、住宅団地の建替えでは、社会的な領域である外部環境の評価 が低いことを、戻り入居者に対するアンタート調査から指摘している。 団地の計画は、単純な「敷地の有効利用」ではなく、社会資本形成的機 能を重視する環境形成的な視点に立ち、21 世紀に向けた居住環境づく りに結び付けるべきだと、結論付けている。

注 8) 村田は、阪神・淡路大震災で発生したコミュニティの崩壊（アイデン ティティ・クライシス）が住民に与えた精神的なダメージに焦点をあて て、再生計画に住民が参加する重要性について論じている。

注 9）曽は、高龄者の視点を通して、団地の社会的な一体性を活かし生態系 を維持することが団地再生の重要な方向性であることを明らかにしてい る。

注 10) 劉は 2002 年に大阪府住宅供給公社の全団地を、新井は 2002 年に千葉 県高根台団地を、增永は 2004 年に大阪府香里が丘団地を対象に、住民 の生活実態と住環境に対寸る評価を含むアンケート調査を行い、その結 果を分析している。

注 11) 国及び地方公共団体に上る建替え事業目標の中心的課題は、住宅建設 計画法に基づいて定められた住宅建設五箇年計画による新築と建替えに よる住宅建設促進による居住水準の向上であり、土地確保等のために、 
既存の住宅団地の敷地の有効利用によって住宅建設戸数を確保する手法 が主流になっていった。

注 12）特に高齢者にとって、住み慣れた地域から強制的に移住させられるス トレスによって精神と肉体が急速に蝕ばれることが、阪神・淡路大震災 の被災者の居住環境の変化に対する様々な研究や調查報告で明らかにさ れている。

注 13)見慣れた景観を形成している古い建築には必ず新築の瞬間があり、古 い建築に価値をおく思想を批判する「新しい建物」を欲する世論はその 矛盾を突く。増田友也は、「Ethnos の風景・素描」のなかで、存在的な 環境世界と人間存在の故郷である原風景を対峙させつつ、絶対時間を超 克し両義性を実践寸る行為である計画の本質を明らかにしてみせた。

注 14）研究の対象とした住宅団地は、1960年代後半から 1970 年代にかけて 地方公共団体と住宅公団が開発した郊外型の中高層の集合住宅団地の内、 貢貸住宅だけで構成されているものを取り上げている。平均住戸面積は、 国土交通省が定める誘導居住水準に满たないため、全面的な建替えを前 提とした再生方法が議論されてきた。

注 15) 公営住宅法第 36 条では、法が定める耐用年数の二分の一の期間が経 過すれば建替え事業のため除却できるとしている。条例でRC 造の公営 住宅の耐用年数は 70 年と決められている。

注 16) 新井は、千葉県の高根台団地の再生事業における福祉ボランティアグ ループの活動で集会所の設計と運営方法に対して居住者側の意見を反映 させたケ一スを報告（注 10）前掲）している。しかし住民の最初の要望 は、コミュニティを毁損して高齢者に負担を強いる全面建替え手法に対 し、住民の意向を反映した既存住棟の改修と部分的な建替えという事業 手法への転換は申立てに止まり、今後の課題となった、と結論している。

注 17) 2003 年の都市公団廃止に伴う付帯決議で、国は、住民団体加らの実効 ある施策の要望に対し、居住者の居住の安定をはかることを約束してい る。その交涉の当事者であった全国公団住宅居住者組合は、居住者の権 利と住環境の保全など具体の対策を求めている。

注 18）S P C は特別目的会社とし、公営住宅法第 44 条の規定を準用するた め、株式会社、任意組合ではなく社団法人格をもつ非営利法人と考えて いる。

注 19) 我が国の組合住宅は提案と挫折の試行錯誤の歴史である。筆者は、組 合住宅の成否は居住権と所有権の明確な区別にあると認識し、S P C に よる資金調達と住民の組織化を対とする考え方を提案した。

注 20) 住宅居住者組合は「住宅と居住に関する住民の諸権利確保」という基 本的な目的に則って消費生活協同組合法に基づく組合と考えている。

注 21）公営住宅法等に基づいて自治体が行っている低額所得者等に対する家 貨の減免制度等の生活支援策は、S P Cが引き継げないため、自治体や 国による住宅支援制度の抜本的な改勒必要となると考えている。

注 22) 高齢者の終身居住権の保障については、高齢者の居住の安定確保に関 わる法律第 56 条及び第 63 条の規定を準用する。当該終身居住権を保証 する場合、地元の社会福祉法人又は自治体と連絡して事業者である S P Cは都道府県にその旨を登録する必要がある。

注 23）S P Cの資金調達には、議決権を有しない優先株の発行、元利偵還保 証の付いた特定証券の発行（証券取引法第 2 条 1 項 19 号）を考えてい る。

注 24) これらの住棟形式は住戸を挟んだ階段式または星形いわれる中央に階 段がある。各住戸へのアプローチは階段で半階分の上下移動を伴う設計 がほとんどである。

注 25）全国集計の場合の社会的要因は外国との間の転出入が対象となる。同 研究所の予測ではで 2025 年 95000 人である。

注 26)「国立社会保障・人口問題研究所」オフィシャルサイトから、世帯数 別で発表される将来推計人ロデータベースを参照している。

注 27) 神戸市都市計画総局住宅部が集計した実績データと、注 26)の予測デ 一夕を詳細にみると、2000 年から 5 年の変化は $\mathrm{E}$ 世代(全国は $5 \%$ 減、 $\mathrm{S}$ 団地は $2 \%$ 増) を除き、極めて近似した数值になる。公営住宅法では、 1996 年から 50 歳以上の高齢者世帯の入居条件が䌅和されており、増减 は社会的な要因が影響していると思われる。

注 28）神戸市から提供された S 団地の他、垂水区のT団地の入退居データと、 大阪府から提供された門真市の $\mathrm{K}$ 団地の入居者の入居時期データから、 10 年間の退居率を想定。 $\mathrm{T}$ 団地は 5 年間年率 $6.1 \%$ (2001 年加 55 年 間)、 $9.3 \%$ (1996 年から 10 年間)、 $\mathrm{K}$ 団地は 2000 年から 5 年間で年率 2. $2 \%$ となっている。

注 29) 大阪府の典型的なベッドタウンとして 1950 年代後半に開発に着手さ れた住宅団地である。前掲の増永が提出した調查報告書を基䃈デー夕 として用いている。
注 30) フィージビリティスタディ/FS と訳される「事業可能性の検証」をい う。ビジネスプランを決定する前の段階で、事業化が可能かどうか、 一般的に集められた情報から整理された仮説的なデータを元に、事業 化の可能性もしくは事業の持続可能性を探る作業をいう。金融機関が 投資の可否を判断する本格的な調查の前に行われるケースも多い。

注 31) 神戸市の T 団地は建替えを予定している貸貸住宅団地であり、入居者 の新規募集を停止している。神戸市は建替えのために高齢世帯の引越を 積極的に進めており、1996 年から 2001 年までは平均的な減少だが、そ れ以降、75 歳を超える 65 藏以上の高齢者世帯の減少率が極めて大きく なっている。(神戸市都市計画総局住宅部の資料から)

\begin{tabular}{|c|c|c|c|c|c|c|c|c|c|c|c|c|c|c|c|c|}
\hline 袁年 & 25- & 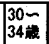 & ${ }_{390}^{35-}$ & 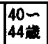 & \begin{tabular}{|l|l|}
455 \\
495
\end{tabular} & \begin{tabular}{|l|l|}
500 \\
54
\end{tabular} & $\mid \begin{array}{l}55 \\
595\end{array}$ & $60-600$ & $765-$ & $\begin{array}{l}70- \\
74\end{array}$ & 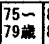 & \begin{tabular}{|l|}
800 \\
84
\end{tabular} & \begin{tabular}{|l|l|}
855 \\
89
\end{tabular} & \begin{tabular}{|l|l|}
900 \\
944
\end{tabular} & 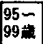 & 100 \\
\hline 48 & 4 & 13 & 15 & 30 & 36 & 48 & 41 & 64 & 67 & 63 & 49 & 30 & 15 & 0 & 1 & \\
\hline $\mathrm{HI}$ & 2 & 1 & 3 & 14 & 20 & 23 & 49 & 43 & 67 & 60 & 52 & 43 & 16 & 11 & 0 & . \\
\hline $\mathrm{H} 18$ & 1 & 2 & 4 & 1 & 7 & 10 & 20 & 32 & 30 & 39 & 28 & 25 & 14 & 4 & 1 & 0 \\
\hline
\end{tabular}

注 32)資金調達先を、安定したキャッシュフローに対する金融貸付ローンを 提供するシニアレンダーと、資産を担保に将来価値を見越して資金を提 供するメザミンレンダーに分けている。ローンは元利均等返済、メザミ ンは資産売却一括返済を条件とする場合が多いが、証券化手法を組み合 わせて短期的に資金を回収する方法もある。

注 33)低所得である従前居住者の家貨に対する家賃補助もしくは生活保護等 の公的な支援の継続が必要である。S P C は、高齡の従前居住者との終 身契約、低所得の一般居住者の定額家貨での居住を保障するには、当該 定額家貨の収受について自治体と協定締結が必要である。自治体が責任 を負うべき居住保障を民間が負うことになるからである。

\section{参考文献}

1) 三宅醇 :「住宅政策から居住政策への模索」、豊橋技術科学大学退官記念 論文集、2004.5

2) 間宫陽介他編 : 公共空間としての都市，都市のシステムと経営、岩波講 座 7,6 -都市の再生を考える-、岩波書店、各 2005.1、2005.5

3）西島芳子 : 公営住宅の改善に関する居住者の意識一低所得階層の住宅需要 に関する研究-日本建築学会計画系論文集、第 371 号、pp. 95-103、1987. 4) 山岡美博 : 公共住宅の高齢者向け住宅・居住改善、日本住宅会議編、『住 宅白書一高龄者と住まいータ、p. 130、ドメス出版、1989.11

5) 山川元 : 公団住宅の建替え問題、日本住宅会議編、『住宅白書一土地問題 とすまいー』、pp. 31-5、ドメス出版、1991.11

6) 瀬戸口镃他：公団貨貸住宅団地における居住者の団地更新意向の類型化 とその特性に関する研究、日本建築学会計画系論文集、第 452 号、 pp. 133-42、1993.10、

7) 竹原祐介他：環境形成的視点から見た公団住宅の建替えに関する研究、 日本建築学会計画系論文集、第 496 号、pp. 81-8、1997.6

8) 村田義郎他 : 公営住宅建替計画策定における住民参加とソーシャルサポ 一トに関する研究：日本建築学会計画系論文集、第 523 号、pp. 171-8、 1999. 9

9) 曾 英敏他: サスティナブル・コミュニティの視点からみた高龄者のため の団地再生計画の研究 : 日本建築学会計画系論文集、第 594 号、pp. 95102、2001.11

10)劉形㣌他 : 公的貨貸集合住宅団地の立地・住環境に対する住民評価、日 本建筑学会計画系論文集、第 581 号、pp. 1-8、2004.7

11)増永理彦：香里団地の再生に関する $\mathrm{D}$ 築居住者の意向について、生活科 学論鋠 VOL 35、松萨女子学院大学学術研究会発行、pp. 65-82、2006, 3

12)田中晃代:ニュータウンにおける持続可能なまちづくりの指標づくりの意 義と方向性に関する研究、都市計画論文集 No. 39-3、pp. 577-82、 2004. 10

13)竹井隆人：金融が鍵を握る住宅組合の発展、季刊すまいろん、pp. 48-53、 住宅総合研究財団、2005. 10

14)国土交通省住宅局編集 : 住宅・建筑ハンドブック 2004、日本住宅協会、 2004. 11

15)国土交通省住宅局総合整備課監修: 公営住宅の整備 H17 版、ベターリビ ング、2005. 5

16)新井信幸：高齢社会における公団㶵貸住宅団地再生計画の基磷的研究： 日本都市計画学会、都市計画論文集、第 39-3 号、pp. 613-8、2004.10

17)增田友也 : Ethnos の風景、増田友也著作集 1、ナカニシヤ出版、pp. 267356、1999.3

18)日本住宅協会 :「昭和の住宅政策を語る」、同協会、1992.5

19)浅見泰司編：住環境-評価方法と理論、東京大学出版会、2001.11 